\title{
Malignant pancreatic gastrinoma in a maned wolf (Chrysocyon brachyurus): case report
}

[Gastrinoma pancreático maligno em lobo-guará(Chrysocyon brachyurus): relato de caso]

\author{
T.F. Carvalho $^{1}$, D.N. Frois ${ }^{1}$, H.P. Tinoco ${ }^{2}$, A.T. Pessanha ${ }^{2}$, T.A. Paixão ${ }^{3}$, R.L. Santos $^{1 *}$ \\ ${ }^{1}$ Escola de Veterinária - Universidade Federal de Minas Gerais - Belo Horizonte, MG \\ ${ }^{2}$ Fundação Zoobotânica de Belo Horizonte - Belo Horizonte, MG \\ ${ }^{3}$ Instituto de Ciências Biológicas - Universidade Federal de Minas Gerais - Belo Horizonte, MG
}

\begin{abstract}
A captive 12-year-old female maned wolf (Chrysocyon brachyurus), previously diagnosed with visceral leishmaniasis, developed severe myiasis in the right ear, followed by prostration and death. A firm solid nodule, measuring 1 x $3 \mathrm{~cm}$, was grossly observed in the pancreas. Histologically, there was neoplastic proliferation in the pancreas and pancreatic lymph node. Neoplastic cells had a neuroendocrine pattern, and were positive for gastrin and pancreatic polypeptide by immunohistochemistry. The wolf had also ulcerative gastritis. To the best of our knowledge is the first reported case gastrinoma in this species.
\end{abstract}

Keywords: maned wolf, Chrysocyon brachyurus, neoplasia, pancreas, gastrinoma

\section{RESUMO}

Uma fêmea lobo-guará de cativeiro (Chrysocyon brachyurus), diagnosticada previamente com leishmaniose visceral, desenvolveu milase grave na orelha direita, seguida por prostação e morte. Um nódulo sólido, firme e medindo $1 \times 3 \mathrm{~cm}$, foi macroscopicamente observado no pâncreas. Histologicamente, observou-se proliferação neoplásica no pâncreas e linfonodo pancreático. As células neoplásicas tinham um padrão neuroendócrino e foram positivas para gastrina e polipeptideo pancreático por imuno-histoquímica. A loba tinha também gastrite ulcerativa. Este é o primeiro caso descrito de gastrinoma nessa espécie.

Palavras-chave: lobo-guará, Chrysocyon brachyurus, neoplasia, pâncreas, gastrinoma

\section{INTRODUCTION}

Gastrinoma is a neuroendocrine tumor that secretes gastrin. It is a rare tumor in dogs and cats (Diroff et al., 2006; Green and Gartrell, 1997), whereas insulinoma is the most common pancreatic neuroendocrine tumor in these species (Green and Gartrell, 1997). Human patients, dogs, and cats with gastrinoma may develop the Zollinger-Ellison Syndrome, which is characterized by increased production of gastrin and consequently hypersecretion of acid by the parietal cells of the stomach, resulting in gastrointestinal erosions and ulcers (Hayden and Henson, 1997).
Although gastrinomas have been initially described as a neuroendocrine tumor of pancreatic origin, in humans, 40 to $60 \%$ of these tumors develop primarily in the duodenal wall, whereas only $20 \%$ actually involve the pancreas (Morrow and Norton, 2009). In contrast, canine and feline gastrinomas are mostly primary of the pancreatic islets (Altschul et al., 1997), with only a few reported cases that developed primarily in the duodenum (Vergine et al., 2005). Importantly, duodenal gastrinomas, in humans and dogs tend to be smaller in size, making the diagnosis in these cases more challenging (Vergine et al., 2005).

Recebido em 9 de fevereiro de 2017

Aceito em 4 de abril de 2017

* Autor para correspondência (corresponding author)

E-mail: rsantos@vet.ufmg.br 
Gastrinomas have a high frequency of malignancy. Approximately 60 to $90 \%$ of human cases are malignant, whereas in $50 \%$ of the cases there are metastasis, mostly to the liver and lymph nodes, by the time of the diagnosis (Morrow and Norton, 2009; Krampitz and Norton, 2013).

The goal of this report is to describe a case of pancreatic gastrinoma in a 12 -year-old female maned wolf (Chrysocyon brachyurus), which to the best of our knowledge is the first reported case in this species.

\section{CASE REPORT}

The wolf was originally from the zoological garden in Goiania (Brazil), and kept in captivity at the Fundação Zoo-Botânica de Belo Horizonte (Belo Horizonte, Brazil) since 2008. The animal had been previously diagnosed with visceral leishmaniasis (Mol et al., 2015), and in January 2015 developed severe myiasis in the right ear, followed by prostration and death.
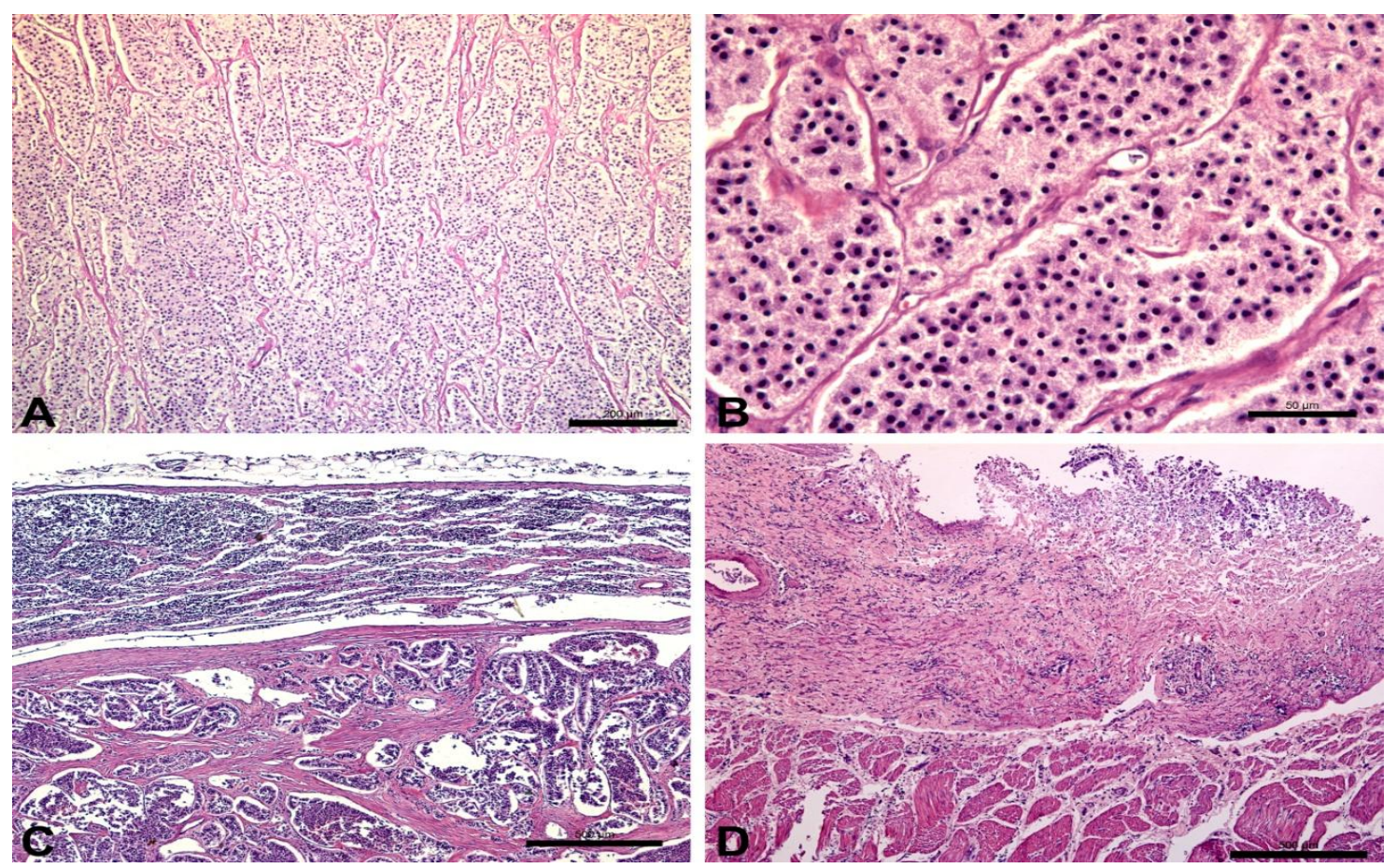

Figure 1. Gastrinoma in a maned wolf (Chrysocyon brachyurus). (A) Pancreas; neuroendocrine neoplasia, with densely cellular neoplastic tissue arranged in islands of sustained by scarce fibro-vascular connective tissue; bar $=200 \mu \mathrm{m}$. (B) Higher magnification of A; bar $=50 \mu \mathrm{m}$. (C) Pancreatic lymph node with metastatic neuroendocrine neoplastic cells, and a compressed pre-existing lymphoid tissue on the top of the micrograph; bar $=500 \mu \mathrm{m}$. (D) Stomach with extensive ulceration associated with inflammatory infiltrate; bar $=500 \mu \mathrm{m}$. Hematoxylin and eosin $(\mathrm{HE})$. 
Immunohistochemistry was performed on sections of pancreas and pancreatic lymph node using the following primary antibodies: insulin (polyclonal guinea pig, 1:300 dilution, code A0564, Dako, USA), gastrin (polyclonal. rabbit anti-human, 1:100 dilution, code RP044-05RUO, Diagnostic BioSystems, USA), pancreatic polypeptide (polyclonal, rabbit, 1:4000 dilution, code RP 030-05, Diagnostic BioSystems, Belgium), and glucagon (polyclonal, rabbit antihuman, 1:300 dilution, code E18182, Spring Bioscience, USA), and the streptavidin-biotinperoxidase detection system (LSAB kit, Dako, USA), and 3,3-diaminobenzidine tetrachloride (Dako, USA) as chromogen. Most neoplastic cells stained positive for gastrin (Figure 2) and pancreatic polypeptide, whereas they were negative for insulin and glucagon, supporting the diagnosis of pancreatic gastrinoma.

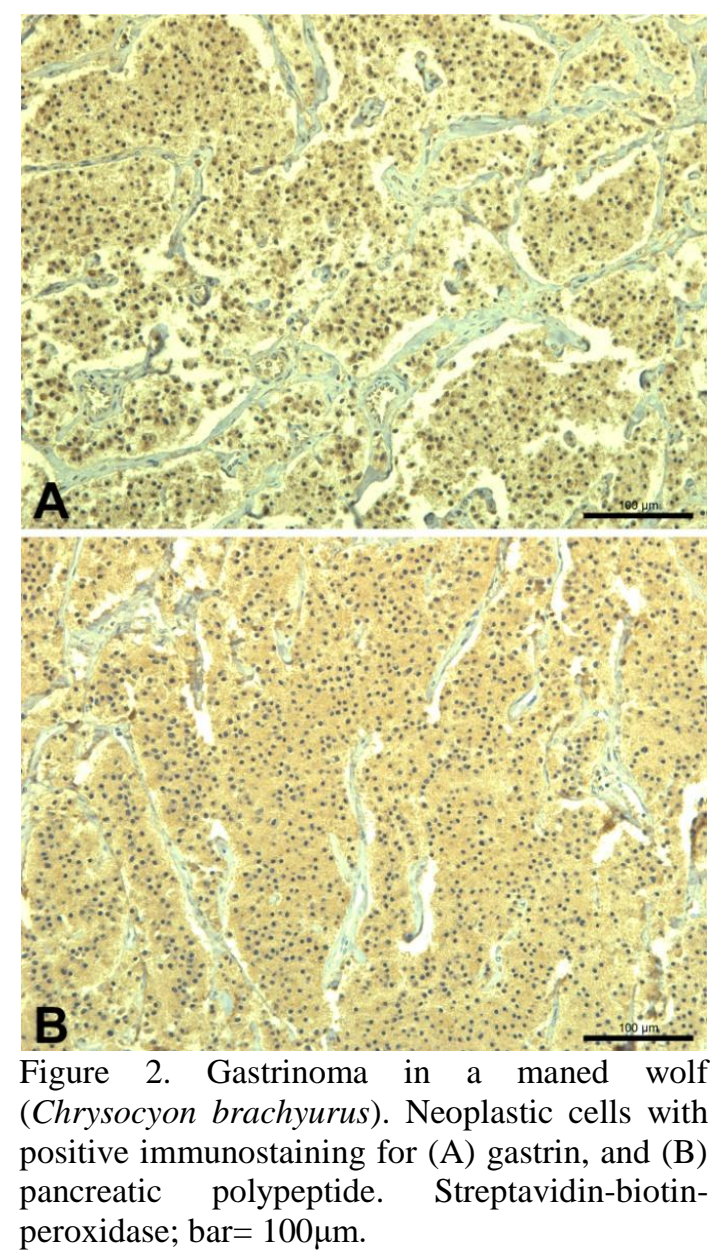

In addition to the neoplasm, there were multiple ulcerations in the stomach (Figure 1), associated with a neutrophilic infiltrate extending into the muscular layer, and thrombi in some of the gastric wall blood vessels. There was marked lymphoid depletion, and moderate amounts of a proteinaceous eosinophilic material in the spleen, confirmed by Red Congo staining, to be amyloid. In the kidneys, there was a mild membranous glomerulopathy and crystalloid material inside tubules and renal pelvis. Lymph nodes other than the pancreatic, had accumulations of large numbers of plasma cells and histiocytes with a few Mott cells. There was also mild centrilobular lipidosis. Considering that some of these lesions, namely amyloidosis and glomerulopathy, could be secondary to visceral leishmaniasis, immunohistochemistry was performed as previously described (Luppi et al., 2008), but did not result in detection of Leishmania antigens in tissues.

\section{DISCUSSION}

Together our histopathology and immunohistochemistry findings fully support the diagnosis of pancreatic gastrinoma. Although other neoplasms have been previously reported in maned wolves (Munson and Montali, 1991), this is the first reported case of gastrinoma in this species. Gastrinomas are uncommon in veterinary medicine. In this case, the senile maned wolf affected was a female, being in good agreement with previous reports, that indicates a more common incidence of this tumor in females (Green and Gartrell, 1997), and among senile dogs and cats with ages ranging from 8.5 to 12 years (Diroff et al., 2006).

In this case, gastric ulcers were likely secondary to gastric acid hypersecretion, as previously reported in cases of gastrinomas (Green and Gartrell, 1997). Clinical signs in dogs and cats include vomiting, weight loss, gastrointestinal ulcers, polydipsia, hematemesis, melena, and fever (Green and Gartrell, 1997). The diagnosis in this case was based on histopathology and immunohistochemistry. Ante mortem diagnosis of this tumor is challenging, particularly in wildlife. Usually the diagnosis is accomplished based on clinical signs after excluding all differentials, imaging, gastrin levels, or post mortem examination (Green and Gartrell, 1997).

Neoplastic cells usually secrete one type of hormone, but they may eventually secrete more 
than one hormone (Vergine et al., 2005). Most of the reports describes immunostaining for gastrin, but not for insulin, and pancreatic polypeptide (Hayden and Henson, 1997; Diroff et al., 2006). However, in a study of 53 gastrinomas, three were also positive for the pancreatic polypeptide (O'Brien et al., 1987), as observed in this case. Gastrin hypersecretion is strongly suggestive of gastrinoma, although some dogs with gastrinoma may have seric levels of gastrin within normal reference values (Vergine et al., 2005).

Shaw (1988) studied eight cases of gastrinomas in dogs, they were all primarily from the pancreas, and five had metastasis for the liver and lymph node. Pancreatic gastrinomas have higher rates of metastasis to the liver than duodenal gastrinomas (Krampitz and Norton, 2013).

In addition to the neoplasm, this maned wolf was infected with Leishmania infantum. Visceral leishmaniasis is endemic in the area were the zoological garden is located (Mol et al., 2015). Likely the splenic amyloidosis and glomerulopathy may be due to Leishmania infection, as previously described in wild canids (Luppi et al., 2008).

In conclusion, to the best of our knowledge this is the first reported case of gastrinoma in a maned wolf, which was associated with metastasis to a local lymph node, and ulcerative gastritis.

\section{ACKNOWLEDGEMENTS}

Work in RLS lab is supported by $\mathrm{CNPq}$ (Conselho Nacional de Desenvolvimento Científico e Tecnológico, Brasil), FAPEMIG (Fundação de Amparo a Pesquisa do Estado de Minas Gerais, Brasil), and CAPES (Coordenação de Aperfeiçoamento de Pessoal de Nível Superior, Brasil). TAP and RLS have fellowships from CNPq (Brasil).

\section{REFERENCES}

ALTSCHUL, M.; SIMPSON, K.W.; DYKES, N.L. et al. Evaluation of somatostatin analogues for the detection and treatment of gastrinoma in a dog. J. Small Anim. Pract., v.38, p.286-291, 1997.
DIROFF, J.S.; SANDERS, N.A.; MCDONOUGH, S.P.; HOLT, D.E. Gastrin-secreting neoplasia in a cat. J. Vet. Intern. Med., v.20, p.1245-1247, 2006.

GREEN, R.A.; GARTRELL, C.L. Gastrinoma: a retrospective study of four cases (1985-1995). $J$. Am. Anim. Hosp. Assoc., v.33, p.524-527, 1997.

HAYDEN, D.W.; HENSON, M.S. Gastrin secreting pancreatic endocrine tumor in a dog (putative Zollinger-Ellison syndrome). J. Vet. Diagn. Invest., v.9, p.100-103, 1997.

KRAMPITZ, G.W.; NORTON, J.A. Current management of the Zollinger-Ellison syndrome. Adv. Surg., v.47, p.59-79, 2013.

LUPPI, M.M.; MALTA, M.C.C.; SILVA, T.M.A. et al. Visceral leishmaniasis in captive wild canids in Brazil. Vet. Parasitol., v.155, p.146-151, 2008.

MOL, J.P.; SOAVE, S.A.; TURCHETTI, A.P. et al. Transmissibility of Leishmania infantum from maned wolves (Chrysocyon brachyurus) and bush dogs (Speothos venaticus) to Lutzomyia longipalpis. Vet. Parasitol., v.212, p.86-91, 2015.

MORROW, E.H.; NORTON, J.A. Surgical management of Zollinger-Ellison syndrome; state of the art. Surg. Clin. N. Am., v.89, p.10911103, 2009.

MUNSON, L.; MONTALI, R.J. High prevalence of ovarian tumors in maned wolves (Chrysocyon brachyurus) at the National Zoological Park. J. Zoo. Wildl. Med., v.22, p.125-129, 1991.

O'BRIEN, T.D.; HAYDEN, D.W.; O'LEARY, T.P.; CAYWOOD, D.D.; JOHNSON, K.H. Canine pancreatic endocrine tumors: immunohistochemical analysis of hormone content and amyloid. Vet. Pathol., v.24, p.308314, 1987.

SHAW, D.H. Gastrinoma (Zollinger-Ellison Syndrome) in the dog and cat. Can. Vet. J. v.29, p.448-452, 1988.

VERGINE, M.; POZZO, S.; POGLIANI, E. et al. Common bile duct obstruction due to a duodenal gastrinoma in a dog. Vet. J., v.170, p.141-143, 2005. 